\title{
Encouraging women's labor force participation in transition countries
}

\section{Government policies can stimulate female labor force participation if coherent and well thought-out}

Keywords: female labor force participation, transition countries, aging, work-life balance, female entrepreneurship

\section{ELEVATOR PITCH}

Increasing women's labor force participation is important to sustainable economic development, especially in economies with highly educated women and an aging population. Women's participation varies across transition countries, driven by such economic and social factors as traditional views of gender roles and limited government support for caregivers. Still, in all countries there is clear scope for policies aimed at increasing women's participation. In particular, in countries where women's educational attainment is already high, policies to support a better work-life balance and female entrepreneurship look particularly promising.

\section{KEY FINDINGS}

\section{Pros}

() The female labor force in transition countries is highly educated.

๑ Low fertility rates are making it easier for women to join the labor force.

( Increasing female labor force participation has the potential to partially offset the negative economic consequences of aging populations.

๑ More flexible labor market arrangements can increase female labor force participation.

๑ Increased female entrepreneurship can lead to higher female labor force participation directly and indirectly and in the short and long term.
In transition countries, female labor force participation has been declining and populations have been aging, 1990-2013

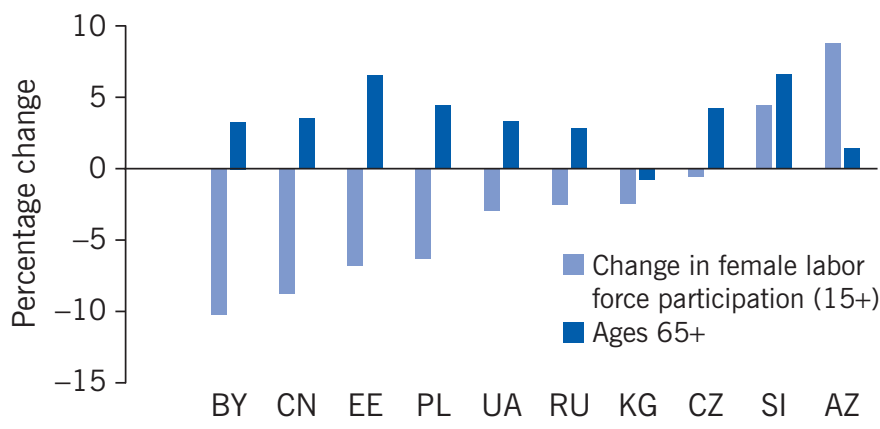

Source: Author's own calculations based on data from World Bank, World Development Indicators database, 2015. Online at: http://data.worldbank. org/data-catalog/world-development-indicators I Z A

\section{Cons}

- Female labor force participation in transition countries is still impeded by traditional views on gender roles and occupational segregation by gender.

- Limited government support for caregivers is exacerbating the trade-off between having children and working.

- Population aging is likely to reduce female labor force participation.

- Limited flexibility in the labor market makes it harder for women to work.

$\ominus$ Women wishing to become entrepreneurs still face substantially larger obstacles than men.

\section{AUTHOR'S MAIN MESSAGE}

The share of women in the labor force in many transition countries is now lower than it was at the beginning of the transition from central planning to market economies. This problem has particularly serious repercussion because fertility rates are falling and populations are aging, further shrinking the labor force. The experience of transition countries reveals that policies to expand women's access to higher education are not enough to ensure higher participation. Also needed are a broad set of reforms to help women achieve a better work-life balance and to encourage expansion in working opportunities. 


\section{MOTIVATION}

Low female labor force participation is a lost opportunity to increase GDP per capita and boost public finances. Getting more women into the labor force would expand (and make better use of) the available talent pool and counter the shrinking labor force in economies with aging populations. Increasing female labor force participation can also support greater investments in education and child health, reducing poverty and increasing overall well-being and long-term economic development.

With so much at stake, it is important to understand what kind of policies can be expected to be effective in boosting female labor force participation. The experience of transition countries is quite revealing in this respect. Despite facing similar challenges in managing the structural transformation from central planning to a market economy, governments of transition countries have been exploring different policies and tailoring them to national goals and priorities. This paper highlights some of the lessons learned from this experience.

\section{DISCUSSION OF PROS AND CONS}

Women living in socialist economies at the beginning of the transition had to cope with epochal changes in the structure of the economy and society. Their choices were also heavily influenced by the way their government responded to the rising challenges. Research shows that the decision of women to participate in the labor force is affected by many economic, social, and cultural factors, some of which change only slowly over time, while others can be affected fairly rapidly by changes in economic and social policies.

\section{Women under socialism}

Countries at the onset of transition shared many characteristics-including the levels of female labor force participation and female educational attainment-because they had shared similar institutions and values for so long.

Under socialism, women's participation in the labor market was considered crucial to the achievement of plan objectives, and female education was encouraged. The investment in women's education was substantial in most countries, so much so that by the early 1990s in many countries women were more educated on average than men, a difference that remains largely true today. Women in transition countries are almost as educated as women in high-income countries and substantially more educated than women in developing countries.

Socialist countries actively encouraged female labor force participation through several means, from propaganda to a variety of policy measures. For example, the state provided working mothers with both maternity benefits and accessible childcare services-often including infant care-which was mostly enterprise based [1]. Women's participation in the labor market was also encouraged by the compressed wage scales within each industry, which were decided in most countries at the central level. Wage compression worked through two channels to affect women's employment. Because of wage compression, a woman re-entering the labor market after a prolonged absence would not receive a substantially lower salary than women who had stayed in the labor 
market. And the low average level of wages also meant that women had to work in order to complement family income.

Overall, these government efforts to encourage greater female labor force participation were successful. However, while women were asked to contribute to the achievement of the economic plan, the traditional perceptions of gender roles-in particular perceptions about women's role in the household-remained relatively unchanged. Women continued to be expected to do the bulk of the household work and caregiving activities even as their participation in the labor market increased. This led to a double burden on women that was only partially alleviated by public policies such as the ones mentioned above. These traditional views of gender roles also affected women's work outside the household. The perception that women were more fit for jobs resembling housekeeping and care-giving affected the opportunities available to women in the labor market. The persistence of traditional gender roles, combined with the fact that part-time employment was uncommon in socialist countries, led women to concentrate in semiskilled-professional occupations in such sectors as health care, education, and retail trades. These occupations tended to have shorter and more flexible working hours, which enabled women to reduce their working time outside the household and to achieve a better work-life balance, even if this meant earning lower wages [2].

\section{The impact of countries' economic and social transition on women}

The collapse of socialist regimes led to fundamental changes in labor market institutions. These changes affected women in different ways and sometimes in opposite directions. For example, while decompression of the wage structure penalized women-who were concentrated in the lower part of the wage distribution-the increase in returns to education favored women, as they were on average more educated than men. These two opposing effects gave rise to different outcomes in different countries. In countries of the former Soviet Union, where minimum wages were not increased to compensate for their loss in real value, women's wages typically lost value relative to men's, while in Central and Eastern European countries, where real minimum wages were preserved to a larger extent, the opposite happened [2].

In the early days of the transition, the formerly socialist countries suffered severe economic and social crises. For women, the impact was intensified by sectoral and occupational segregation by gender and a strengthening of traditional gender roles. This confluence of factors led to substantial fluctuations in female labor force participation and to diverging trends in female and male labor force participation. Initially, in most transition countries, men were hit hardest, as the economic restructuring affected mostly male-dominated sectors. As men's labor force participation declined sharply, women's participation declined less or, in some cases, increased as women tried to compensate for the loss of income suffered by the household (a phenomenon referred to in the literature as the "added worker effect"; Figure 1).

However, in some countries women later lost their relatively stronger initial position as more women than men left the labor force, even women in female-dominated sectors [3], [4], [5]. This trend can be ascribed both to changes in the incentive structure and to women's greater preference than men for job stability, which sometimes seems to have limited women's ability to benefit from working in growing sectors. Another 
Figure 1. Men's labor force participation relative to women's changed considerably from the

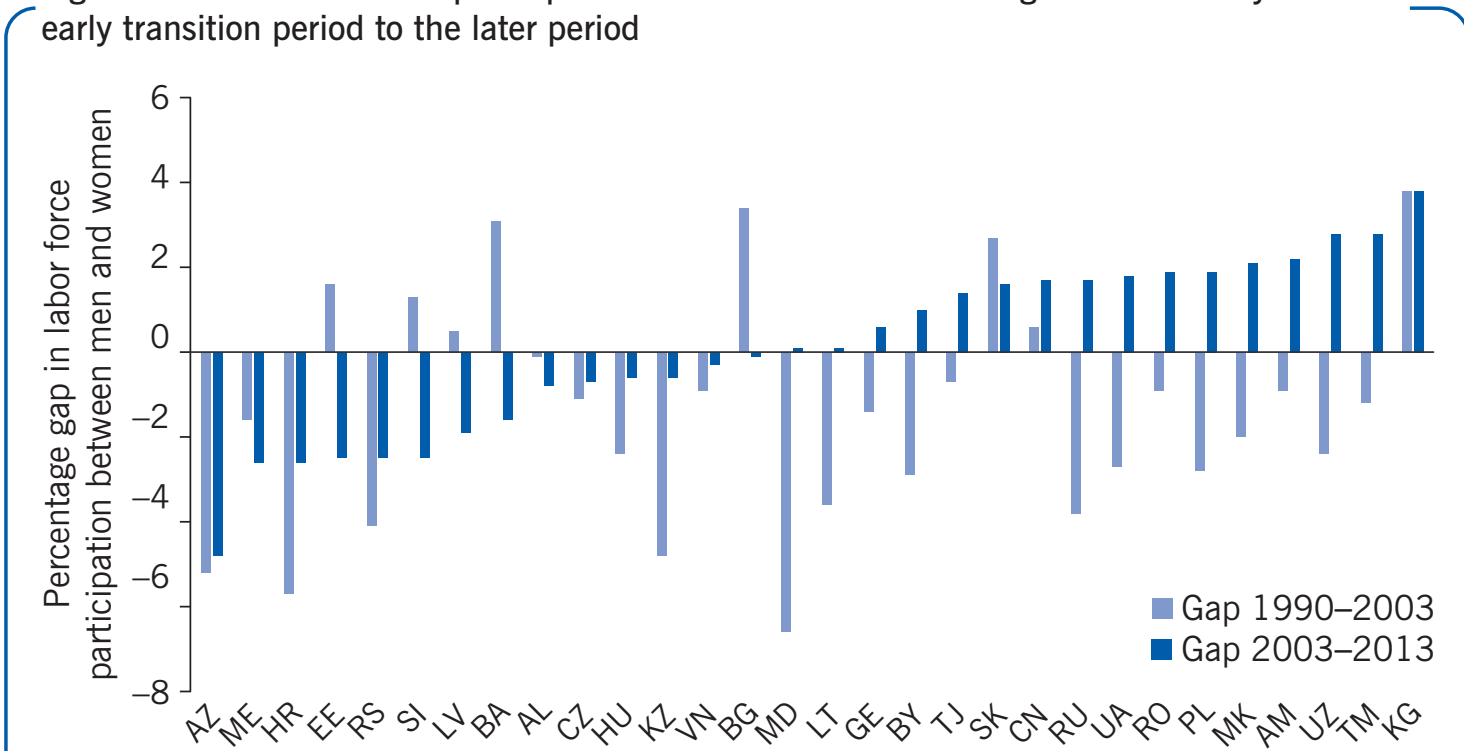

Source: Calculations based on data from World Bank, World Development Indicators database, 2015.

Online at: http://data.worldbank.org/data-catalog/world-development-indicators

contributing factor to the widening of the gender labor force participation gap has been the failure of many countries to generate sufficient high-quality job opportunities for women. In several transition countries, especially where unemployment rates were high and during earlier phases of transition, men were preferred over women in hiring decisions. All these factors delayed the entry or re-entry of women into the labor market and might have contributed to an increase in the number of "discouraged" women who abandoned the labor force.

\section{Government policies and female labor force participation}

Government policies have played a crucial role in changing the incentive structure faced by women in transition countries. First, as a response to the downsizing of the state sector and to the associated increase in unemployment, many countries introduced incentives for early retirement that prompted many older women, especially those with lower skills, to exit the labor force. At the same time, due to the shrinking of the public budget and the closure or privatization of state-owned enterprises, the supply of public and firm-based childcare services shrank. The growth of new private childcare centers was initially too slow to make up for this loss. As a consequence, households were simultaneously confronted with a declining supply and quality of childcare and rising childcare cost. The increased uncertainty, reduced earnings, and reduced access to (more expensive) childcare services negatively affected fertility rates.

To offset some of the negative effects on fertility rates, a common solution was to increase maternity benefits by extending the length of maternity leave. This shift from external childcare to homecare created new incentives for women with young children to leave the labor force or, at the least, to delay their return to work. This had a negative effect on the labor force participation of women with children, reducing their 
likelihood of remaining in the labor force and the employment share of women in the labor market [1], [6], [7].

The cases of Estonia and Slovenia are particularly telling in this respect. At the outset of transition, these two countries had an almost identical approach to maternity leave and public childcare, Later, their systems diverged. Estonia lengthened pregnancy and maternity leave, while Slovenia left them unchanged. Moreover, in Estonia the number of childcare establishments shrank by $14 \%$ and prices rose, while in Slovenia prices did not change and the number of establishments increased by $1 \%$. Not surprisingly, over the period under observation (the late 1980s and early 1990s), Estonian women were much more likely to leave the labor market than Slovenian women. Consequently, after the first five years of transition, the employment share of Slovenian women had increased, while that of Estonian women had decreased [6].

The smaller supply of childcare services also affected women's labor force participation on the demand side, together with the more general contraction in the education sector. As these sectors employed mainly women, labor demand for women also contracted. The reduction in the number of jobs and in real wages in these sectors contributed further to the decline in female labor force participation. The impact of these changes was stronger on less-skilled women and increased the risk of poverty for their households.

Tax system changes are another way that governments of transition countries have influenced women's incentives to work. Tax changes such as the introduction of joint taxation at the household level have affected the taxation of married women's employment income. Joint taxation increases the marginal tax rate of secondary earners and lowers that of primary earners. The introduction of joint taxation in the Czech Republic in 2005, for example, reduced women's probability of working and, to a lesser extent, the number of hours they worked [8].

Monetary transfers to poor families, intended to ease the condition of the most vulnerable households, also reduced labor force participation, particularly for women, by increasing the opportunity cost of becoming employed. This happened, for example, in Albania's anti-poverty program, Ndihma Ekonomike, which was introduced to support poor households. The program had a negative impact on the labor supply, particularly among women and urban residents.

Governments have also attempted to stimulate labor force participation through active labor market policies, such as wage subsidy programs, training, education, and short-term interventions to strengthen job search skills. A recent survey of the evidence concludes that such measures have been effective in raising women's probability of employment and their transition from unemployment to employment [9]. These effects were particularly strong for older and less-skilled women, the two categories for which labor force participation rates have declined the most since the beginning of transition.

\section{Aging societies: A double challenge for women}

Most transition countries are experiencing a demographic transformation, with the share of the population older than 65 years of age increasing steadily since the 1990s. This demographic trend presents a double challenge for most countries. 
First, the share of the population that is of working age (generally those aged 15-64) continues to shrink. Despite recent reforms of the pension systems, in most countries the effective pension age remains below 65 years. Women are typically allowed to retire earlier than men. Slowing the shrinking of the labor force will require raising the effective retirement ages for men and, particularly, for women. This step is unlikely to be enough on its own, however. Workplaces will have to adjust to the needs of elderly workers, to facilitate their continuing participation in the labor force. Information campaigns and anti-discrimination policies should also be considered. All of this, however, makes sense only if the labor market is capable of generating opportunities for older workers as well as for younger generations.

There is also another way in which aging populations are inhibiting women's labor supply. In addition to childcare, women's care-taking responsibilities often extend to the elderly and to family members with disabilities. In transition countries, where fertility rates have often dropped below the replacement rate after transition, the need for elder-care has increased and will continue to do so inexorably. Informal elder-careunpaid care provided by family members-is common in developed countries. The evidence suggests that this phenomenon is even more pervasive in transition countries. In a recent comparative study of EU countries, for example, the two Eastern European countries in the sample-Poland and the Czech Republic-had the highest incidence of informal care, at close to $100 \%$. This finding suggests that informal care for the elderly and people with disabilities will be an increasingly relevant issue for women.

Under these conditions, theory predicts an increase in the opportunity cost (the cost of forgone alternatives) of out-of-home work and, therefore, a negative impact on female labor force participation. While there are no detailed and rigorous studies of the impact of informal elder-care on female labor force participation in Eastern and Central European transition countries, studies for China, which is also transitioning from a planned to a market economy, find that women's care-taking responsibilities have been increasing. While simple co-residence with elderly family members is found to have positive impacts on women's labor force participation, studies focusing on elder-care needs have found it to have a negative impact on women's work outside the home [10]. The same is true in the case of co-residence with younger family members with disabilities.

\section{Increasing female labor force participation by supporting female entrepreneurship}

A potentially promising intervention in transition countries to encourage female labor force participation-and, more generally, greater social inclusion of women-is support for female entrepreneurship. Such support can be especially effective in countries with a culture that perpetuates traditional gender roles and with limited employment opportunities. Female entrepreneurs not only create jobs for themselves but may also generate employment opportunities for other women. Female entrepreneurs are less likely than male entrepreneurs to discriminate against women and more likely to hire them. Most important, female entrepreneurship can have powerful indirect and longlasting effects by modeling entrepreneurship for younger generations of women and by helping to transform deeply rooted cultural norms and gender stereotypes that limit women's options in the labor market [11]. Starting such virtuous cycles can lead to 
both greater labor force participation of women and, more generally, to their greater economic and social inclusion.

In most transition countries, unlike in developing countries, few women turned to selfemployment as the transition process got under way. Most women held on to their formal jobs as long as they could and then looked for other formal or informal jobs or left the labor market. A possible (and partial) explanation for this pattern comes from a study of female entrepreneurs in Lithuania and Ukraine at the end of the first decade of transition [11]. The study suggests that the low initial levels of female entrepreneurship in transition countries might have been due to the difficulties women encountered at the onset of transition when they attempted to start their own businesses. Women faced more obstacles than men did because of the intensification of traditional cultural norms and gender stereotypes, whose effects were amplified by the female labor market segregation inherited from socialist times. For example, women were disadvantaged compared with men by the smaller size and the weaker power of their networks. Female entrepreneurs in Lithuania and Ukraine faced resistance because they were perceived as challenging traditional gender roles [11]. This resistance made it harder for women not only to access capital and government support but also to find experienced entrepreneurs who could mentor and advise them. But female survey respondents in Lithuania and Ukraine also reported several factors that supported their entrepreneurship, including backing from the men in their families and from emerging business associations.

As time passed, the number and the share of women engaged in entrepreneurial activities increased in most transition countries, reaching levels comparable to those in more developed Western European countries. The average share of enterprises owned by women was 36\% in Europe and Central Asia (including Turkey) and 39\% in the EU10 countries, according to the European Bank for Reconstruction and Development-World Bank Business Environment and Enterprise Performance Surveys (BEEPS). Women's participation in firm ownership ranged from $60 \%$ in the Kyrgyz Republic to just under $11 \%$ in Albania and Azerbaijan. However, female entrepreneurs in transition countries appear to be mostly necessity driven (to cope with missing job opportunities or economic shocks to the household) rather than opportunity driven (to take advantage of the most profitable employment opportunities), the type of entrepreneurship that contributes most to job creation and economic growth. Necessity driven entrepreneurs typically have access to fewer resources, develop smaller firms, and generate less knowledge and positive economic spillovers than opportunity driven entrepreneurs. On a positive note, regardless of differences in motivation between male and female entrepreneurs and in the characteristics of the enterprises they establish, once women decide to become entrepreneurs, they are as likely to succeed as men [12].

The evidence for developing and transition countries suggests that governments can do a lot to support female entrepreneurs, in particular to increase the scale of their activities and their probability of success. But government policies have to be designed carefully, based on the needs of particular target groups of women. For example, female entrepreneurs, especially those who are poor, seem to benefit more when financial support is coupled with intensive training and follow-up visits tailored to their specific economic activities. Better-off women will need less comprehensive support. Another interesting finding for several transition countries is that receiving 
in-kind capital increases the probability of success of female entrepreneurs by helping women retain more control over their entrepreneurial activities and re-invest in their business. A similar effect has been associated with savings programs and payment instruments that allow women greater privacy and control over the revenues generated by their economic activities [13].

\section{Path-dependency: Why links between the past and the future make acting now so important}

Female labor force participation is the result of a complex interaction of factors, some of which can be changed and will have effects within a fairly short time, while others take much longer. Analyses of the labor market experience of women in transition countries and more broadly reveal the existence of strong path-dependency: the factors determining female labor force participation today will also affect female labor force participation many years from now, through a multitude of channels, including the transmission of gender roles from one generation to the next. This path-dependency means that government policies affecting women's incentives to participate in the labor market can have long-lasting effects that extend well beyond women's labor force participation in the short term.

\section{LIMITATIONS AND GAPS}

To increase women's participation in economic activity, it is crucial that policymakers take into account the potential consequences of government policy options and that government policies constantly adapt to current challenges and anticipate future challenges. Gaining this understanding requires closing some gaps in the literature on female labor force participation in transition countries. Particularly important in a context of aging populations and potentially shrinking labor forces is to understand the impact of informal care responsibilities on female labor force participation and to identify the most effective policies for reducing women's double burden. Equally important is to learn more about the impediments to female entrepreneurship. The design of effective policies to support female entrepreneurship requires a better understanding of what helps women in transition countries become successful entrepreneurs, what prevents them from doing so, and what serious constraints female entrepreneurs face at the beginning as well as later.

\section{SUMMARY AND POLICY ADVICE}

The full participation of women in economic activities and their inclusion in the development process are important for contributing to economic growth and development, but they are especially important in a context of aging populations and low fertility rates The experience of transition countries teaches us that achieving full inclusion of women is complex and difficult, requiring careful assessment of incentives and constraints that women face in their everyday life.

Women in transition countries have always had to struggle to allocate their limited time across many competing activities inside and outside the home. The transition 
process and its socio-economic consequences forced them to rethink their role in society. Many women-especially older and less-skilled women-reacting to their weaker position in the labor market and the rising opportunity costs associated with their home responsibilities, withdrew from the labor market. Those who did not found themselves struggling to withstand the increasing pressures on their lives.

Under current socio-economic trends, the pressures on women are only likely to intensify. Governments seeking to maintain or increase female labor force participation will have to focus on reducing the opportunity costs and increasing the benefits of working.

A first step should be to reduce some of the obstacles to women's participation in the labor market. Governments should reconsider their role as providers of childcare, elder-care, and care for people with disabilities. Delivering such services directly or providing financial support to help families acquire such services in the marketplace can make it easier for women to work by reducing their double burden and lowering the opportunity cost of working. That is especially the case for less-educated or less-skilled women, whose potential earnings are lower. Greater support from the government may also ease the trade-off between having children and deciding to work, potentially leading to greater labor market participation and higher fertility, and possibly attenuating future imbalances between the working-age population and the dependent population (youth and elderly). Another important step would be to promote more flexible work arrangements and new cultural models that would allow a more equitable distribution of the burden of household production, including care-taking, among men and women in the household and the achievement of a more satisfactory work-life balance.

Removing obstacles, however, is just one part of an ideal government strategy to increase female labor force participation. To attract more women to the labor market, the economy will need to generate more appealing working opportunities. Devoting substantial resources to programs supporting female entrepreneurship and tailored to the socio-economic context should constitute a key part of government policies aiming to create higher quality jobs and encouraging greater participation by women.

Finally, governments can increase women's incentives to enter the labor market by removing fiscal disincentives, such as the joint taxation of household members.

\section{Acknowledgments}

The author thanks two anonymous referees and the IZA World of Labor editors for many helpful suggestions on earlier drafts

\section{Competing interests}

The IZA World of Labor project is committed to the IZA Guiding Principles of Research Integrity. The author declares to have observed these principles.

(c) Norberto Pignatti 


\section{REFERENCES}

\section{Further reading}

ILO. Global Employment Trends for Women 2012. Geneva: ILO, 2012.

UNECE. Access to Financing and ICT: Women Entrepreneurs in the ECE Region. Geneva: United Nations, 2004.

\section{Key references}

[1] Grogan, L., and K. Koka. "Young children and women's labour force participation in Russia, 1992-2004." Economics of Transition 18:4 (2010): 715-739.

[2] Brainerd, E. "Women in transition: Changes in gender wage differentials in Eastern Europe and the former Soviet Union.” Industrial and Labor Relations Review 54:1 (2000): 138-162.

[3] Orazem, P. F., and M. Vodopivec. "Winners and losers in transition: Returns to education, experience, and gender in Slovenia." The World Bank Economic Review 8:2 (1995): 201-230.

[4] Lauerova, J. S., and K. Terrell. "What drives gender differences in unemployment?" Comparative Economic Studies 49:1 (2007): 128-155.

[5] Smith, K. "Labor force participation in the Soviet and post-Soviet Baltic states." Economic Change and Restructuring 44:4 (2011): 335-355.

[6] Orazem, P. F., and M. Vodopivec. "Male-female differences in labor market outcomes during the early transition to market: The cases of Estonia and Slovenia." Journal of Population Economics 13:2 (2000): 283-303.

[7] Loskshin, M., and M. Fong. "Women's labour force participation and child care in Romania." Journal of Development Studies 42:1 (2006): 90-109.

[8] Kalíšková, K. "Labor supply consequences of family taxation: Evidence from the Czech Republic." Labour Economics 30:C (2014): 234-244.

[9] Todd, P. E. Effectiveness of Interventions Aimed at Improving Women's Employability and Quality of Work: A Critical Review. World Bank Policy Research Working Paper No. 6189, 2012.

[10] Liu, L., X. Y. Dong, and X. Zheng. "Parental care and married women's labor supply in urban China.” Feminist Economics 16:3 (2010): 169-192.

[11] Aidis, R., F. Welter, D. Smallbone, and N. Isakova. "Female entrepreneurship in transition economies: The case of Lithuania and Ukraine." Feminist Economics 13:2 (2007): 157-183.

[12] Nikolova, E., R. Frantisek, and D. Simroth. Entrepreneurship in the Transition Region: An Analysis Based on the Life in Transition Survey. EBRD Working Paper No. 141, February 2012.

[13] Buvinic, M., and R. Furst Nichols. "Promoting women's economic empowerment: What works?” The World Bank Research Observer 2:1 (2014): 186-201.

\section{Online extras}

The full reference list for this article is available from:

http://wol.iza.org/articles/encouraging-womens-labor-force-participation-in-transitioncountries

View the evidence map for this article:

http://wol.iza.org/articles/encouraging-womens-labor-force-participation-in-transitioncountries/map 